\title{
ASTHMA
}

\section{T cell cytokine profiles in childhood asthma}

\author{
V Brown, T J Warke, M D Shields, M Ennis
}

Thorax 2003;58:311-316

See end of article for authors' affiliations

.........................

Correspondence to: Professor M Ennis, Department of Clinical Biochemistry, Institute of Clinical Sciences, Queen's University Belfast, Belfast

B12 6BJ, UK;

m.ennis@qub.ac.uk

Revised version received 20 November 2002

Accepted for publication

4 December 2002

\begin{abstract}
Background: An imbalance of T cell subsets in asthma with a predominance of Th2 type cells has been proposed. The aim of this study was simultaneously to detect surface markers and intracellular production of cytokines in T cells from the airways of children with and without asthma.

Methods: Bronchoalveolar lavage (BAL) fluid was obtained by wedging a suction catheter into the distal airway immediately before elective surgery. Cells were stimulated with phorbol 12-myristrate 13-acetate (PMA) and ionomycin and intracytoplasmic cytokine retention was achieved using monensin. The cells were stained with the relevant antibodies and analysed by flow cytometry.

Results: No statistical difference was observed between children with atopic asthma, atopic non-asthmatic subjects, and normal controls in the percentage of CD3+ cells producing interleukin (IL)-2 or IL-4. Interferon (IFN) $\gamma+$ T cells were, however, present in a much higher percentage than either IL-2 or IL-4 positive cells. The percentage of IFN $\gamma+\mathrm{T}$ cells was significantly increased in subjects with atopic asthma (median 71.3\%, interquartile range (IQR) 65.1-82.2, $n=13$ ) compared with both atopic nonasthmatic subjects (51.9\%, IQR 37.2-70.3, $\mathrm{n}=12), \mathrm{p}<0.05$ and normal controls $(58.1 \%, \mathrm{IQR} 36.1-$ 66. 1, $\mathrm{n}=23$ ), $\mathrm{p}<0.01$.

Conclusions: These findings indicate that IFN $\gamma$ producing $T$ cells are more abundant in the airways of children with atopic asthma than in atopic non-asthmatic subjects and controls. The proinflammatory activities of IFN $\gamma$ may play an important role in the pathogenesis of childhood asthma and may suggest that asthma is not simply a Th2 driven response.
\end{abstract}

$\mathrm{T}$ he inflammatory response in asthma is associated with airway hyperresponsiveness and involves a number of different cell types including eosinophils, basophils, mast cells, and $\mathrm{T}$ lymphocytes. Recent findings in human and animal models indicate a crucial role for the Th2 subclass of CD4+ cells in asthma. The two subclasses of $\mathrm{T}$ helper cells-Th1 and Th2-differ in their production of cytokines which are thought to antagonise the pathological consequences of each other. Th1 and Th2 cells were originally described in mice. ${ }^{1}$ Although human CD4 T cells have similar cytokine profiles to the murine cells, they are not identical and therefore are usually defined as interferon (IFN) $\gamma($ Thl) and interleukin (IL)-4 (Th2) producing cells since IL-2, IL-6, and IL- 10 cytokines are not solely produced by a single subset. Th2 cytokines activate mechanisms important in defence against parasites and in allergic inflammation including IgE production, mast cell differentiation and maturation, migration and activation of eosinophils. Thl lymphocytes are important in defence against viruses and bacteria. Th2 lymphocytes are increased in the airways of patients with atopic asthma, and the presence of IL-5 and possibly IL-4 producing cells correlates with disease severity in bronchial biopsy specimens and bronchoalveolar lavage (BAL) fluid..$^{-4}$

Several single cell assays have been developed that allow the measurement of Thl/Th2 cytokine expression-for example, limiting dilution assay, ELISPOT, and in situ hybridisation. However, the main limitation with all these methods is the inability to analyse the simultaneous expression of different cytokines by individual cells. Flow cytometry has proved to be a more powerful tool for the measurement of the frequency of cytokine producing cells using intracellular methods. This method allows multiple colour staining to demonstrate exclusive or mutual coexpression of different cytokines in individual cells following short term activation, thus allowing the characterisation of $\mathrm{T}$ cell subsets on the basis of cytokine expression rather than just surface markers.

This study was undertaken to elucidate the T cell subsets involved in early childhood asthma using intracellular staining methods and to test the hypothesis that BAL fluid T cells in allergic asthma are of the Th2 phenotype.

\section{METHODS \\ Subjects}

Sixty children (40 boys) undergoing elective surgery for a non-inflammatory condition were recruited from the Royal Belfast Hospital for Sick Children. A detailed respiratory and allergy history and serum IgE measurements were used as previously described to categorise the children as atopic asthmatic (A) $(\mathrm{n}=18)$, "non-wheezers with atopy" (NA) $(\mathrm{n}=14)$, and non-atopic, non-asthmatic controls $(n=28$; table 1$) .^{5}$ All children were considered free from recent upper respiratory tract infections. Parents gave written informed consent and the study was approved by the research ethics committee of the Faculty of Medicine, Queen's University, Belfast.

\section{Antibodies and reagents}

Glutamine, mercaptoethanol, penicillin, RPMI 1640, sodium pyruvate, and streptomycin were purchased from Gibco (Paisley, UK). Ionomycin, monensin, paraformaldehyde, phorbol 12-myristrate 13-acetate (PMA), and saponin were obtained from Sigma-Aldrich (Poole, UK). AB serum was purchased from ICN Biochemicals (Hampshire, UK). Anti-CD3 FITC (mouse IgG2a, S4.1), anti-IL2 R-PE (rat IgG2a, MQ1-17H12), anti-IL4 R-PE (rat IgG1, MP4-25D2), anti-IFN $\gamma$ R-PE (mouse $\operatorname{IgG1}, \mathrm{B} 27)$, and isotype matched directly conjugated antibodies were purchased from Caltag Laboratories (California, USA).

\section{Sampling and processing of BAL fluid}

Non-bronchoscopic BAL was performed as previously described. ${ }^{6}$ Briefly, following intubation an 8 FG neonatal suction catheter was inserted and wedged in a distal bronchus and sterile normal saline $(20 \mathrm{ml})$ was injected and immediately aspirated. Total, differential, and mast cell counts were performed as previously described ${ }^{6}$ by a blinded observer. 
Table 1 Characteristics of study subjects and differential cell counts in bronchoalveolar lavage (BAL) fluid

\begin{tabular}{llll}
\hline & $\mathrm{A}(\mathrm{n}=18)$ & $\mathrm{NA}(\mathrm{n}=14)$ & $\mathrm{N}(\mathrm{n}=\mathbf{2 8 )}$ \\
\hline $\mathrm{M} / \mathrm{F}$ & $14 / 4$ & $9 / 5$ & $16 / 12$ \\
Median (range) age (years) & $7.1(4.5-11.5)$ & $8.5(2.1-11.8)$ & $7.9(3.0-13.9)$ \\
Volume return of BAL fluid (ml) & $28.9(20.0-37.5)$ & $25.0(20.0-35.6)$ & $23.7(20.0-29.0)$ \\
Total cell count $\left(\times 10^{5}\right.$ cells/ml) & $1.2(0.8-1.9)$ & $1.1(0.8-2.0)$ & $1.3(0.9-1.8)$ \\
Macrophages (\%) & $46.3(38.0-56.2)$ & $70.1(38.7-94.2)$ & $66.7(43.9-78.4)$ \\
Lymphocytes (\%) & $0.1(0.0-0.6)$ & $0(0.0-0.3)$ & $0(0.0-0.7)$ \\
Neutrophils (\%) & $2.4(1.6-6.7)$ & $1.6(0.7-20.4)$ & $1.6(0.4-5.6)$ \\
Eosinophils (\%)* & $1.0(0.4-2.7)$ & $0.8(0.1-1.4)$ & $0.1(0.0-0.2)$ \\
Epithelial cells (\%) & $41.1(3.9-56.4)$ & $15.1(0.8-27.5)$ & $23.0(11.3-40.0)$ \\
Mast cells $(\%)^{*}$ & $0.05(0.02-0.37)$ & $0.0(0.0-0.02)$ & $0.0(0.0-0.04)$ \\
Blood neutrophils (\%) & $46.8(39.7-56.8)$ & $38.5(34.2-47.3)$ & $40.0(36.4-48.3)$ \\
\hline
\end{tabular}

Data are shown as median (IQR).

$A=$ atopic asthmatics; $N A=$ non-asthmatics with atopy; $N=$ non-atopic, non-asthmatic controls.

${ }^{*} \mathrm{p}<0.05 \mathrm{~A} \vee \mathrm{NA} ;{ }^{* *} \mathrm{p}<0.001 \mathrm{~A} \vee \mathrm{N}$.

Intracellular cytokine detection of BAL fluid T cells was performed as previously described. ${ }^{7}$ BAL fluid cells were resuspended in RPMI 1640 containing $2 \mathrm{mM}$ L-glutamine, $1 \mathrm{mM}$ sodium pyruvate, $100 \mu \mathrm{g} / \mathrm{ml}$ streptomycin, $100 \mathrm{U} / \mathrm{ml}$ penicillin, $0.5 \mu \mathrm{g} / \mathrm{ml}$ amphotericin B, $20 \mu \mathrm{M}$ mercaptoethanol, and $5 \% \mathrm{AB}$ serum. Cells were either unstimulated or stimulated with PMA ( $10 \mathrm{ng} / \mathrm{ml})$ plus ionomycin $(1 \mu \mathrm{M})$ for 5 hours at $37^{\circ} \mathrm{C}$ in $5 \% \mathrm{CO}_{2}$ atmosphere in the presence of monensin $(2.5 \mu \mathrm{M}$ final concentration $){ }^{8}$ The cells were harvested, washed once in phosphate buffered saline (PBS), and fixed for 10 minutes in $4 \%$ paraformaldehyde (PFA). They were then washed twice in PBS and permeabilisation was performed by incubation in $0.1 \%$ saponin buffer for 1 hour. Anti-CD3 (FITC, $1 \mu \mathrm{g} / \mathrm{l} \times 10^{6}$ cells) and anti-cytokine antibodies (IL2-PE,
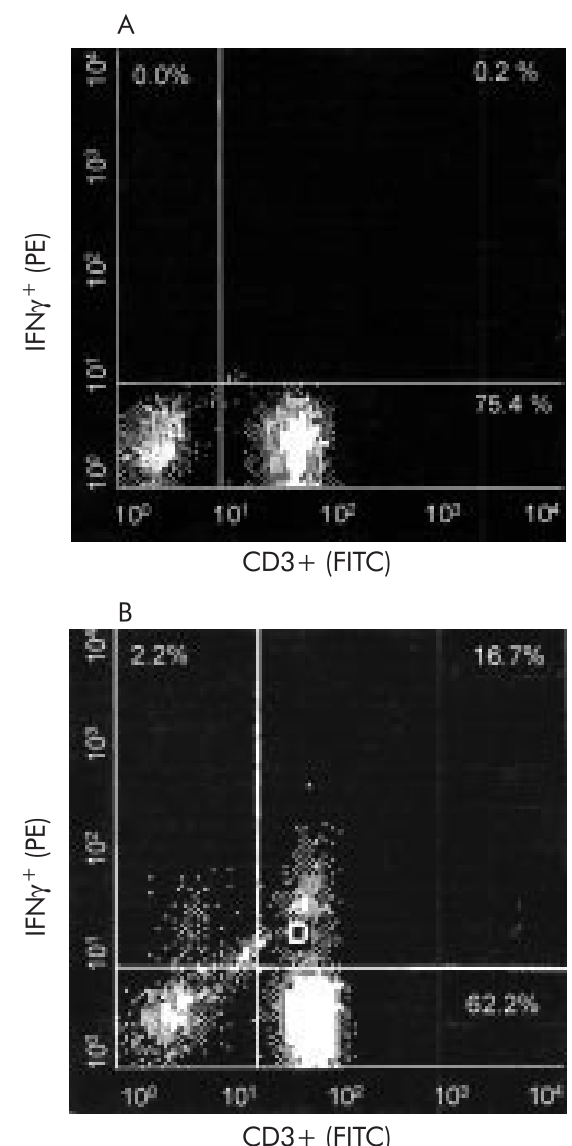

Figure 1 Percentage of IFN $\gamma+/ C D 3+$ in $(A)$ unstimulated and $(B)$ stimulated BAL fluid cells.
IL4-PE and IFN $\gamma$-PE, $1 \mu \mathrm{g} / 1 \times 10^{6}$ cells) were added to the cell suspension and incubated for 20 minutes at $4^{\circ} \mathrm{C}$ in the dark. Samples were washed in permeabilisation buffer to remove unbound antibodies and resuspended in PBS for immediate flow cytometric analysis.

Because of the small volumes and low cell numbers obtained from paediatric BAL and the internalisation of the CD4 molecule by PMA and ionomycin, ${ }^{9}$ all intracellular cytokine measurements were carried out after setting the gate around $\mathrm{CD} 3+\mathrm{T}$ cells. The threshold of $\mathrm{CD} 3+$ cells and cytokine producing positive cells was set using isotype matched, directly labelled non-specific antibodies in identical concentrations and labelled with the same fluorochrome. To ensure that the lymphocyte gate was accurately placed, the back gating approach was always employed..$^{10}$

Listmode data were acquired on a Coulter Epics Elite fourcolour cytometer equipped with an argon ion laser. Typically 250-1000 events were acquired, depending on the number of cells. Because of the low levels of IL-2 and IL-4 in some subjects, cytokine positive T cells often appeared as a shoulder in the flow cytometric histogram. Hence, discrimination between positive and negative cells (isotype controls) was set using the Immuno-4 software programme (Coulter). This programme used the Overton method of channel-by-channel histogram subtraction ${ }^{11}$ to compare histograms generated by cells stained with the anti-cytokine antibodies and an identical number of cells stained with the isotype control. The mean channel fluorescence (MCF)-the difference between the mean channel fluorescence of cells stained with the cytokine specific antibody and the MCF of the cells stained with the isotype matched irrelevant control antibody-was determined as a measure of the intensity of cytokine specific staining.

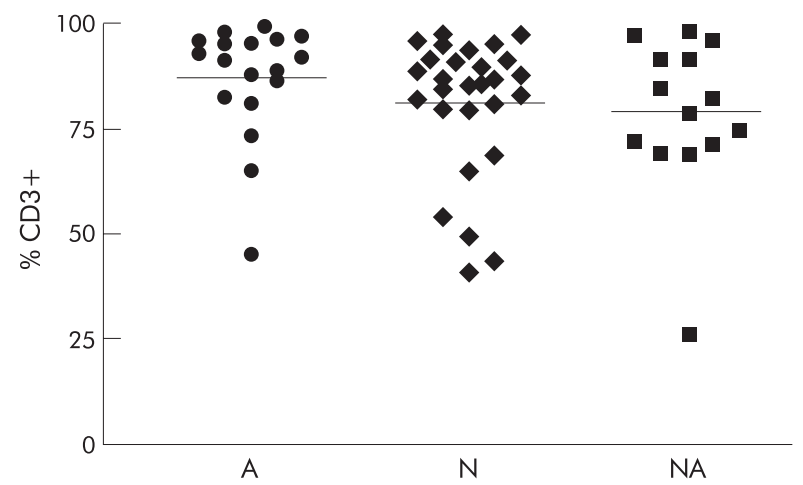

Figure 2 Percentage of $C D 3+T$ cells in BAL fluid from atopic asthmatics (A), non-asthmatics with atopy (NA), and non-asthmatic non-atopic controls (N). 

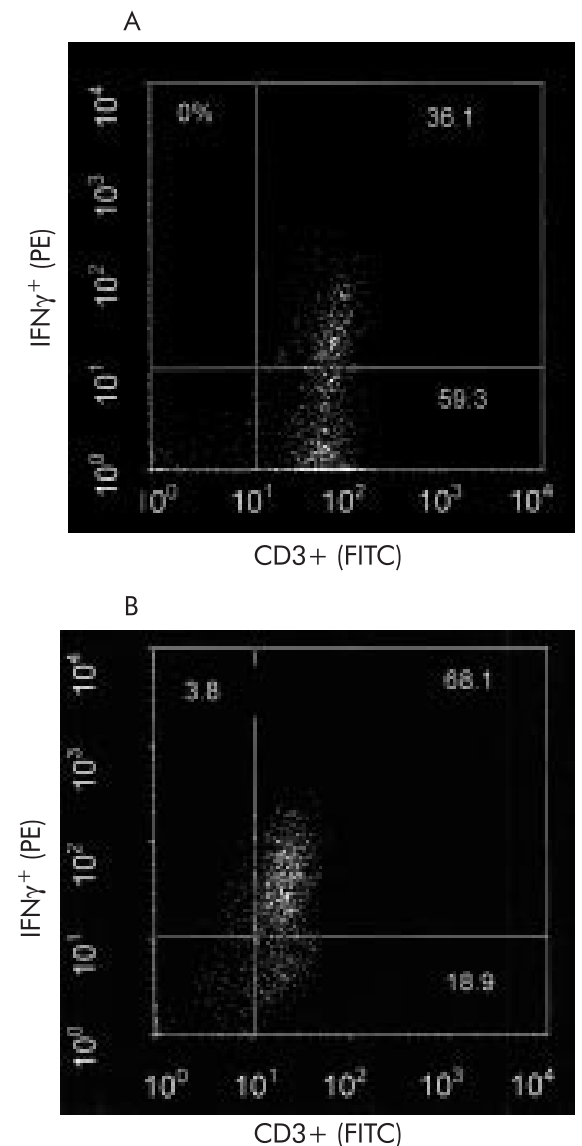

Figure 3 Percentage of IFN $\gamma+/ C D 3+$ in BAL fluid from (A) a non-asthmatic, non-atopic control and (B) an asthmatic subject.

\section{Statistical analysis}

The results are expressed as median (interquartile range, IQR). Differences between groups were determined using the Kruskal-Wallis test. If the Kruskal-Wallis test detected a significant difference, post hoc testing was performed using the Dunn's multiple comparison test with p values of $<0.05$ being considered significant.

\section{RESULTS}

The total number of cells and the percentages of macrophages, lymphocytes, neutrophils or epithelial cells did not differ between the three groups of subjects analysed (table 1). However, the percentage of eosinophils was significantly higher in atopic asthmatic subjects than in controls $(\mathrm{p}<0.001)$, and the percentage of toluidine blue stained mast cells was higher in those with atopic asthma than in non-asthmatic atopic subjects $(\mathrm{p}<0.05$, table 1$)$.

Time course experiments revealed that incubation with PMA, ionomycin and monensin for 5 hours was optimal for the detection and analysis of all three cytokines (data not shown). Unstimulated BAL cells expressed virtually no intracellular cytokines, even in the presence of monensin (fig l). The optimum concentration of monensin $(2.5 \mu \mathrm{M})$ that gave maximal inhibition of protein secretion was determined using whole blood samples from healthy controls (data not shown).

No differences in the median percentage of $\mathrm{CD} 3+\mathrm{T}$ cells were observed in any of the groups analysed (A, 91.2\% (81.895.9), $\mathrm{n}=18$; NA, $80.2 \%$ (69.8-93.5), $\mathrm{n}=14$; controls $(\mathrm{N})$, $86.0 \%$ (79.4-91.0), $\mathrm{n}=28, \mathrm{p}=0.24$; fig 2 ). Typical dot plots of gated lymphocytes from BAL fluid after double staining with anti-IFN $\gamma$ and anti-CD3 are shown in fig 3. A significant difference was observed in the percentage of IFN $\gamma+\mathrm{T}$ cells between the three groups $(p=0.007)$. Using Dunn's multiple comparison test, IFN $\gamma+\mathrm{T}$ cells occurred significantly more frequently in atopic asthmatic subjects (71.3\% (65.1-82.1)) than in either the atopic non-asthmatic group $(51.9 \%$ $(37.2-70.3), p<0.05)$ or non-asthmatic, non-atopic controls (58.1\% (36.1-66.1), p<0.01; table 2, fig 4A). No difference was observed between any of the groups in the frequency of $\mathrm{IL}-2+/ \mathrm{CD} 3+$ or IL- $4+/ \mathrm{CD} 3+\mathrm{T}$ cells from BAL fluid $(\mathrm{p}=0.94$ and $\mathrm{p}=0.42$, respectively; table 2 , fig $4 \mathrm{~B}$ and $\mathrm{C}$ ).

Using the Student's $t$ test, we observed that asthmatic subjects taking inhaled corticosteroids had significantly lower levels of IL-4 $+\mathrm{T}$ cells than those on $\beta_{2}$ agonists or not currently on any asthma medication $(p=0.003$, fig 5$)$.

Although no difference was observed in the intensity of staining (as measured by mean channel fluorescence, MCF) of any of the cytokines in the three groups, the intensity of IFN $\gamma$ staining was significantly higher in all three groups than IL-4 and IL-2 $(\mathrm{p}<0.0001$, table 2$)$. Low cell numbers restricted the analysis of the ratio of IFN $\gamma$ to IL- 4 or IL-2.

\section{DISCUSSION}

Flow cytometry has become an important tool for the analysis of functional subsets in mixed $\mathrm{T}$ cell populations using intracellular staining methods. However, methods for the staining of intracellular cytokines have not been standardised and discrepancies in intracellular data may be partially the result of different stimulation, fixation, and permeabilisation protocols or due to inclusion of insufficient subjects to detect differences. Several groups have reported the flow cytometric detection of intracellular cytokines in allergic disease in whole blood, $^{12}{ }^{13}$ peripheral blood mononuclear cells (PBMCs), ${ }^{14}$

\begin{tabular}{|c|c|c|c|}
\hline & Asthmatics ( $n=18$ ) & $\begin{array}{l}\text { Normal subjects with } \\
\text { atopy }(n=14)\end{array}$ & Normal controls $(n=28)$ \\
\hline $\begin{array}{l}\text { \%ll2+/CD3+ } \\
\text { MCF } \\
n\end{array}$ & $\begin{array}{l}8.9(4.1-23.7) \\
1.4(0.9-1.9) \\
14\end{array}$ & $\begin{array}{l}8.4(4.8-19.7) \\
1.4(1.2-3.0) \\
7\end{array}$ & $\begin{array}{l}7.73(6.0-15.0) \\
1.5(1.2-1.8) \\
22\end{array}$ \\
\hline $\begin{array}{l}\text { \%ll } 4+/ C D 3+ \\
\text { MCF } \\
n\end{array}$ & $\begin{array}{l}15.2(2.3-23.0) \\
1.7(1.4-2.1) \\
10\end{array}$ & $\begin{array}{l}3.9(2.1-12.1) \\
1.7(1.0-2.0) \\
8\end{array}$ & $\begin{array}{l}4.8(2.1-19.8) \\
1.3(0.8-2.0) \\
13\end{array}$ \\
\hline $\begin{array}{l}\% \mathrm{IFN} \gamma+/ \mathrm{CD} 3+ \\
\mathrm{MCF} \\
\mathrm{n}\end{array}$ & $\begin{array}{l}71.3(65.1-82.2)^{*} \\
3.3(2.0-4.6) \\
13\end{array}$ & $\begin{array}{l}51.9(37.2-70.3) \\
2.2(1.8-3.4) \\
12\end{array}$ & $\begin{array}{l}58.1(36.1-66.1) \\
2.6(1.6-4.1) \\
23\end{array}$ \\
\hline
\end{tabular}

Data are shown as median (IQR) values.

*Significantly different from atopic non-asthmatic and normal control subjects. 

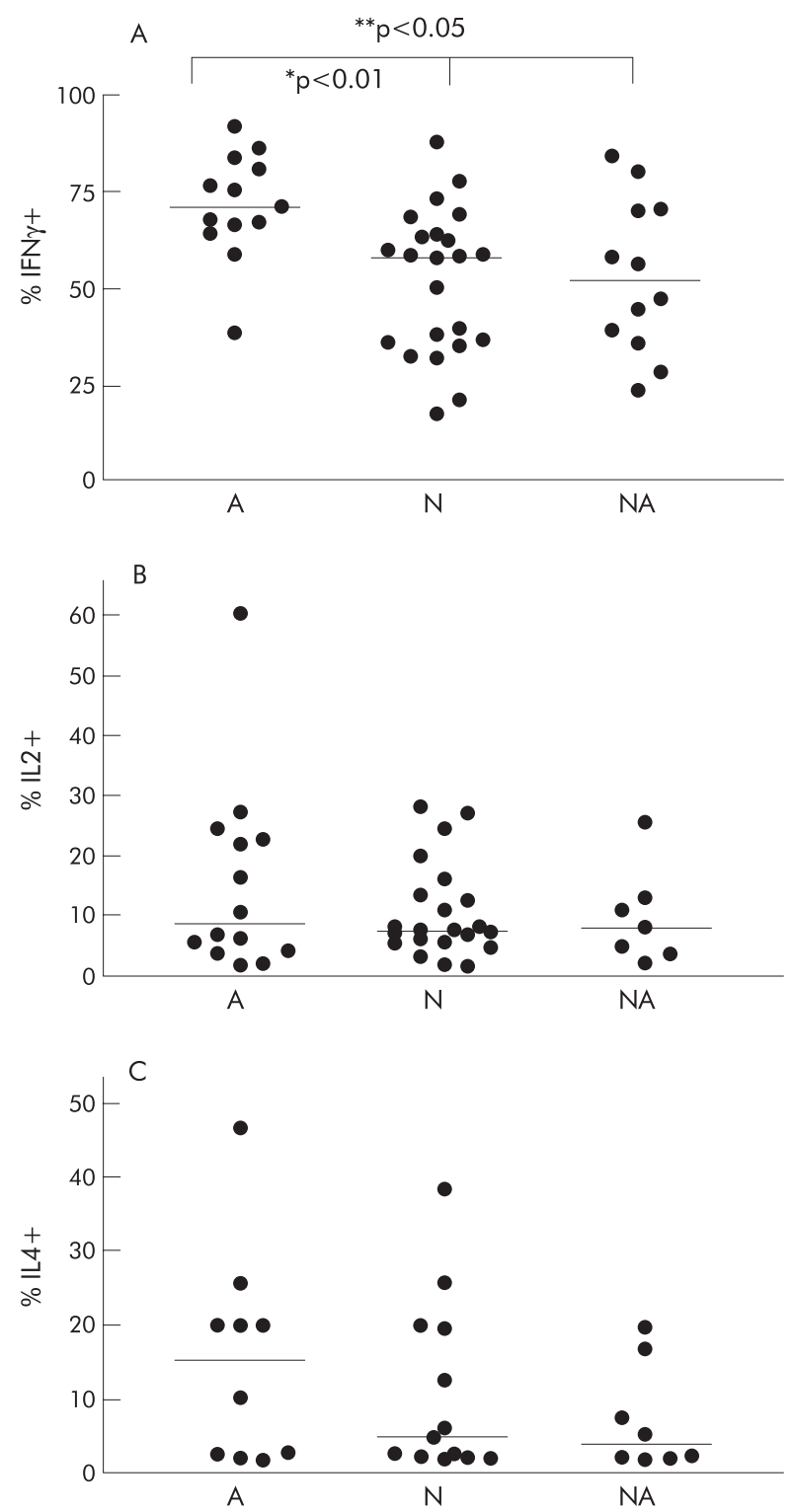

Figure 4 Percentage of (A) IFN $\gamma+/ C D 3+$, (B) IL-2+/CD3+, and (C) $\mathrm{IL}-4+/ \mathrm{CD} 3+\mathrm{T}$ cells in BAL fluid from atopic asthmatic subjects (A), non-asthmatics with atopy (NA), and non-asthmatic, non-atopic controls (N).

cloned T cells, ${ }^{16}$ and in BAL fluid T cells. ${ }^{7}$ However, to date there are no reports on intracellular cytokines in T cells in BAL fluid from children with and without asthma.

We have shown for the first time that the frequency of IFN $\gamma$ producing $\mathrm{T}$ cells is significantly higher in BAL fluid from atopic asthmatic children than either atopic non-asthmatic subjects or normal controls. In parallel with this, IFN $\gamma+$ / $\mathrm{CD} 3+$ cells are more dominant than IL-2+/CD3+ and IL-4+/ $\mathrm{CD} 3+$ cells. Although surprising, these results in children support the only other published work carried out using flow cytometry to assess intracellular cytokine profiles in BAL fluid from patients with allergic asthma. ${ }^{7}$ Furthermore, cultured BAL fluid cells from adult asthmatic patients showed a significant increase in spontaneous and induced IFN $\gamma$ release as measured by ELISA compared with controls. ${ }^{18}$ Whole blood cultures from adult asthmatics have increased levels of IFN $\gamma+/ C D 8+$ in T cells which relates to asthma severity, bronchial hyperresponsiveness, and blood eosinophilia. ${ }^{13}$ Increased serum IFN $\gamma$ concentrations have previously been reported in asthmatic subjects, ${ }^{19}$ including those with acute severe

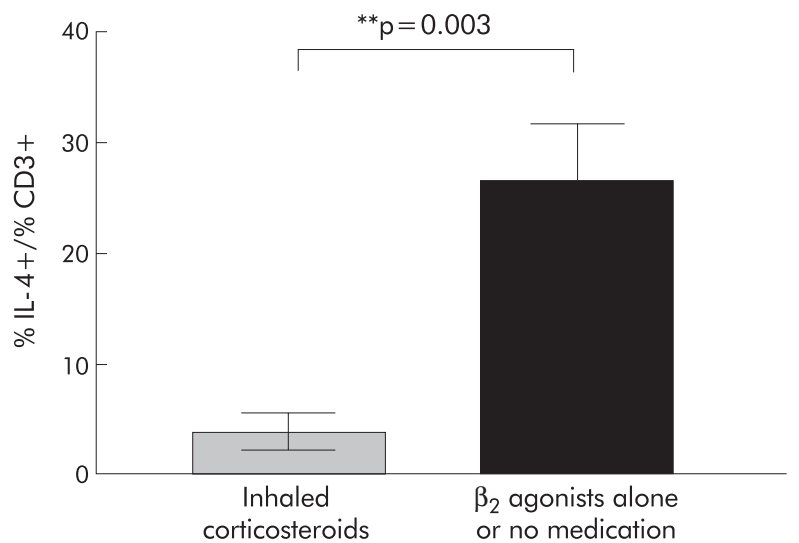

Figure 5 Percentage of IL-4+/CD3+ T cells in asthmatic subjects who were reported to be taking inhaled corticosteroids $(n=5)$ compared with those on $\beta_{2}$ agonists alone or not on any asthma medication $(n=5)$.

asthma, ${ }^{20}$ and the levels correlated with increased airway responsiveness to methacholine. ${ }^{19}$ In other inflammatory conditions such as atopic dermatitis there is increased expression of IFN $\gamma$ mRNA cells in the inflammatory skin lesion ${ }^{21}$ and IFN $\gamma$ has also been shown to play a potential role in nasal polyposis. ${ }^{22}$ The undetectable spontaneous release of intracellular cytokines from paediatric BAL fluid T cells supports previous findings in adult BAL fluid and PBMCs from children. ${ }^{7324}$ Contradictory results have shown a reduction in IFN $\gamma$ production from cultured PBMCs, as measured by ELISA, in wheezy children with or without atopy, ${ }^{25}$ and in atopic children with asthma compared with non-atopic children with asthma and non-atopic controls, ${ }^{24}$ although "mildly atopic" children-including those with asthma ${ }^{23}$ and those with non-atopic asthma ${ }^{24}$-had similar levels of IFN $\gamma$ to controls. In situ hybridisation and polymerase chain reaction experiments found no differences in IFN $\gamma$ mRNA between patients with atopic asthma, atopic controls, and non-atopic controls in adult BAL fluid and biopsy specimens. ${ }^{46}$ Treatment of ovalbumin sensitised mice with anti-IFN $\gamma$ abolishes the development of airway hyperresponsiveness. ${ }^{27}$ These findings, combined with our results and those of others showing increased IFN $\gamma$ in patients with atopic asthma, suggest that under certain circumstances the Th2 hypothesis is not correct.

In agreement with the one published study using adult BAL fluid cells, ${ }^{7}$ we did not observe any differences in the percentage of intracellular IL-2 or IL-4 producing T cells between any of the groups studied. Similar results were found when PBMCs were examined for IL-4+/CD4 cells. ${ }^{28}$ Some studies suggest that there is an increase in IL-2 mRNA and protein in BAL fluid cells and biopsy specimens from mildly atopic asthmatics compared with controls, ${ }^{4}{ }^{29}$ while others have shown no differences in IL-2 mRNA in sputum cells between asthmatic subjects and controls ${ }^{30}$ and in BAL fluid cells following allergen challenge. ${ }^{3}$ Since IL-2 can be expressed by both Thl and Th2 T cells, the role of IL-2 in allergic asthma is still controversial and unclear.

Although the importance of IL-4 in isotype B cell switching to IgE has been well documented, its role in allergen induced recruitment of eosinophils and bronchial hyperresponsiveness is controversial. Some animal studies suggest that IL-4 is important for the recruitment of eosinophils to the airways, ${ }^{3132}$ while others have reported that eosinophil recruitment is independent of the presence of IL-4. ${ }^{33}{ }^{34}$ Similar to the study with adult BAL fluid, ${ }^{7}$ there was a trend for an increase in the percentage of IL-4+ T cells in children with asthma compared with controls, but this did not achieve statistical significance. This may be because of the well documented downregulation of both mast cell and T cell IL-4 
mRNA by corticosteroids $\mathrm{s}^{35-37}$ and $\beta$ agonist induced upregulation of IL-4 in vitro, ${ }^{38}$ since the asthmatic patients who were on inhaled corticosteroids at the time of the analysis had the lowest frequency of IL-4+ T cells. Although a number of studies indicate increased IL-4 (mRNA and protein) production in BAL fluid and biopsy specimens from asthmatic adults ${ }^{49}{ }^{40}$ and in PBMCs,${ }^{24}$ whole blood, ${ }^{41}$ and serum ${ }^{42}$ from children with asthma, none of these studies is directly comparable with the results of our study because of the different protocol and sampling technique. In addition, T cells (CD4+ and CD8+) are not the sole source of IL-4 since it is also expressed by eosinophils and mast cells in both atopic and non-atopic asthma. ${ }^{43}{ }^{44}$ Furthermore, mRNA expression may not necessarily correlate with cytokine secretion, ${ }^{45}$ and the frequency of cytokine positive cells may not directly equate to secreted cytokine levels since the levels in the supernatant might be altered during cell culture. Contradictory results have been reported in PBMCs from children with atopic dermatitis with regard to the correlation between intracellular and secreted cytokine production. ${ }^{17}{ }^{45}$ The results presented here on intracellular IL-4 are concordant with studies measuring the frequency of IL-4+ T cells in BAL fluid and PBMCs. ${ }^{74}$

More recently, the Th2 cytokine IL-13 has also been implicated in the pathogenesis of asthma, with significantly increased expression in BAL fluid from asthmatic subjects following endobronchial challenge which correlated with eosinophilia. ${ }^{46}{ }^{47}$ IL-13 shares many similarities with IL-4, and studies suggest that IL- 13 expression dominates that of IL-4 in allergen challenged asthmatics so it may be a more important cytokine in asthmatic airways. ${ }^{16} 48$

Asthma was originally regarded as a Th2 mediated inflammatory response but recent reports suggest that this theory is too simplistic and question whether distinct $\mathrm{T}$ cell populations exist. ${ }^{49} 50$ The concept that the immune response may switch towards a type 2 response with time or disease progression is also important and may explain why there are discrepancies in cytokine data in allergic asthma. Evidence to support such a concept comes from reports in subjects with atopic asthma which suggest a shift in cytokine production in BAL fluid T cells towards a predominantly Th2 pattern following allergen challenge which is preceded by a $\mathrm{T}$ cell profile involving IFN $\gamma .^{316}$ Thepen et $a l^{51}$ reported a biphasic response to aeroallergens in subjects with atopic dermatitis, although results from this study showed an initial Th2 response followed by IFN $\gamma$ production.

It is well documented that respiratory viruses trigger asthma exacerbations $s^{52} 53$ and children with viral bronchiolitis may develop chronic wheezing that is independent of allergy. ${ }^{54}$ Viral respiratory tract infections typically induce a Thl response, characterised by high levels of IFN $\gamma^{55}{ }^{56}$ which enhances the antiviral activities of effector cells and also plays a pivotal role in virus induced inflammation..$^{57}$ A recent study suggests that a Th2 response may develop in atopic children despite high levels of IFN $\gamma^{58}$ Furthermore, studies in mice suggest that IFN $\gamma$ producing $\mathrm{T}$ cells may be essential for the migration of Th2 cells to the airways. ${ }^{59}$ It may therefore be plausible that RSV induced IFN $\gamma$ producing cells are essential in the enhancement of a Th2 response.

Although flow cytometry is now widely used in the investigation of intracellular cytokine activity in inflammatory conditions such as asthma, there is still need for the standardisation of such procedures including stimulation time, permeabilisation and stimulation agents, Golgi apparatus blockers, and antibodies. Evaluation of cytokine production has been based predominantly on activation of cells with non-physiological polyclonal stimuli such as PMA and ionophore, or PHA, or anti-CD3 and anti-CD28, and therefore may not directly represent in vivo activity to antigens. Although PMA/ionomycin and the superantigen Staphylococcus entertoxin B yield similar cytokine profiles, ${ }^{60}$ stimulation of human $\mathrm{T}$ cell clones with house dust mite antigen induced a smaller IFN $\gamma$ response than PMA and ionomycin. ${ }^{61}$ It may therefore be important to examine whether a non-specific stimulus is equivalent to physiological activation for the purposes of the experiment.

The use of BAL fluid rather than circulating T cells as a tool for investigating cytokine expression in airway diseases is more informative since it focuses on the site of the allergic reaction. Comparison of our results with those from intracellular cytokine measurements in BAL fluid from allergic asthmatic subjects indicates a predominance of IFN $\gamma$ producing T cells in BAL fluid compared with IL-2 and IL-4 and an increased level of T cells expressing IFN $\gamma$ in atopic asthmatic subjects compared with normal controls. ${ }^{78}$ The results presented here provide further evidence to argue against the simplistic Th2 hypothesis for asthma.

It has been proposed that intracellular measurements of cytokines in conjunction with other techniques such as proliferative responses, apoptosis, and cellular cycle may further the study of lymphocyte function in immune responses. ${ }^{62}$ Further work involving coexpression of cytokines, identification of the relevant $\mathrm{T}$ cell subsets, and association between intracellular and secreted cytokines may provide new insights into the role of cytokines in inflammatory processes in the lung and possible new treatment strategies.

\section{ACKNOWLEDGEMENTS}

This work was supported by grants from the National Asthma Campaign (UK), Research and Development Office, DHSS (Northern Ireland), and The Royal Belfast Hospital for Sick Children.

\section{Authors' affiliations}

V Brown, T J Warke, M Ennis, Department of Clinical Biochemistry, Queen's University Belfast, Belfast, UK

M D Shields, Department of Child Health, Queen's University Belfast

\section{REFERENCES}

1 Mosmann TR, Cherwinski H, Bond MW, et al. Two types of murine helper T-cell clone. 1. Definition according to profiles of lymphokine activities and secreted proteins. J Immunol 1986;136:2348-57.

2 Humbert M, Corrigan CJ, Kimmitt P, et al. Relationship between IL-4 and IL-5 mRNA expression and disease severity in atopic asthma. Am J Respir Crit Care Med 1997; 156:704-8

3 Robinson DS, Hamid Q, Bentley A, et al. Activation of CD4+ T cells, increased Th2-type cytokine mRNA expression, and eosinophil recruitment in bronchoalveolar lavage after allergen challenge in patients with atopic asthma. J Allergy Clin Immunol 1993;92:313-24.

4 Robinson DS, Hamid Q, Ying S, et al. Predominant TH2-like bronchoalveolar T-lymphocyte population in atopic asthma. N Engl J Med 1992;326:298-304.

5 Stevenson EC, Turner G, Heaney LG, et al. Bronchoalveolar lavage findings suggest two different forms of childhood asthma. Clin Exp Allergy 1997;27: 1027-35.

6 Heaney LG, Stevenson EC, Turner G, et al. Investigating paediatric airways by non-bronchoscopic lavage: normal cellular data. Clin Exp Allergy 1996;26:799-806.

7 Krug N, Madden J, Redington AE, et al. T-cell cytokine profile evaluated at the single cell level in BAL and blood in allergic asthma. Am J Respir Cell Mol Biol 1996;14:319-26.

8 Dinter A, Berger EG. Golgi-disturbing agents. Histochem Cell Biol 1998; 109:571-90.

9 Petersen CM, Christensen El, Andresen BS, et al. Internalization, lysosomal degradation and new synthesis of surface membrane CD4 in phorbol ester-activated T-lymphocytes and U-937 cells. Exp Cell Res 1992;201:160-73.

10 Loken MR, Brosnan JM, Bach BA, et al. Establishing optimal lymphocyte gates for immunophenotyping by flow cytometry. Cytometry 1990;11:453-9

11 Overton WR. Modified histogram subtraction technique for analysis of flow cytometry data. Cytometry 1988;9:619-26.

12 Ferry B, Antrobus P, Huzicka l, et al. Intracellular cytokine expression in whole blood preparations from normals and patients with atopic dermatitis. Clin Exp Immunol 1997;1 10:410-7.

13 Magnan AO, Mely LG, Camilla CA, et al. Assessment of the Th1/Th2 paradigm in whole blood in atopy and asthma: increased IFN-gamma-producing CD8(+) T cells in asthma. Am J Respir Crit Care Med 2000;161:1790-6

14 Schuerwegh AJ, De Clerck LS, De Schutter L, et al. Flow cytometric detection of type 1 (IL-2, IFN-gamma) and type 2 (IL-4, IL-5) cytokines in T-helper and T-suppressor/cytotoxic cells in rheumatoid arthritis, allergic asthma and atopic dermatitis. Cytokine 1999;11:783-8. 
15 Campbell DE, Fryga AS, Bol S, et al. Intracellular interferon-gamma (IFN $\gamma$ ) production in normal children and children with atopic dermatitis. Clin Exp Immunol 1999;1 15:377-82.

16 Bodey KJ, Semper AE, Redington AE, et al. Cytokine profiles of BAL T cells and T-cell clones obtained from human asthmatic airways after local allergen challenge. Allergy 1999;54:1083-93

17 Krug N, Erpenbeck VJ, Balke K, et al. Cytokine profile of bronchoalveolar lavage-derived $\operatorname{CD} 4(+), C D 8(+)$, and gammadelta T cells in people with asthma after segmental allergen challenge. Am J Respir Cell Mol Biol 2001;25:125-31.

18 Cembrzynska-Nowak $M$, Szlarze $E$, Inglot $A D$, et al. Elevated release of tumor necrosis factor-alpha and interferon-gamma by bronchoalveolar leukocytes from patients with bronchial asthma. Am Rev Respir Dis 1993; 147:291-5.

19 tenHacken NHT, Oosterhoff Y, Kauffman HF, et al. Elevated serum interferon- $\gamma$ in atopic asthma correlates with increased airways responsiveness and circadian peak expiratory flow variation. Eur Respir $J$ 1998;11:312-6

20 Corrigan CJ, Kay AB. CD4 T-lymphocyte activation in acute severe asthma. Am J Respir Dis 1990;141:970-7.

21 Grewe M, Gyufko K, Schopf E, et al. Lesional expression of interferon-gamma in atopic eczema. Lancet 1994:343;25-6.

22 Sanchez-Segura A, Brieva JA, Rodriguez C. T lymphocytes that infiltrate nasal polyps have a specialized phenotype and produce a mixed Th1/Th2 pattern of cytokines. J Allergy Clin Immunol 1998;102:953-60.

23 Tang $M$, Kemp A, Varigos G. IL4 and interferon gamma production in children with atopic disease. Clin Exp Immunol 1993;92:120-4.

24 Tang ML, Coleman J, Kemp AS. Interleukin-4 and interferon-gamma production in atopic and non-atopic children with asthma. Clin Exp Allergy 1995:25:515-21.

25 Leech SC, Price JF, Holmes BJ, et al. Nonatopic wheezy children have reduced interferon-gamma. Allergy 2000;55:74-8.

26 Glare EM, Divjak M, Bailey $M$, et al. The usefulness of competitive PCR: airway gene expression of IL-5, IL-4, IL-4 $\delta 2$, IL-2, and IFN $\gamma$ in asthma. Thorax 2001:56:541-8.

27 Hessel EM, Van Oosterhout AJ, Van Ark I, et al. Development of airway hyperresponsiveness is dependent on interferon-gamma and independen of eosinophil infiltration. Am J Respir Cell Mol Biol 1997; 16:325-34.

28 Gagro A, Rabatic S, Ivancic I, et al. Detection of intracellular cytokines in human lymphocytes and monocytes at the single cell level by flow cytometry. Periodicum Biologorum 1999;101:17-26.

29 Ying S, Durham SR, Corrigan CJ, et al. Phenotype of cells expressing mRNA for TH2-type (interleukin 4 and interleukin 5) and TH1-type (interleukin 2 and interferon gamma) cytokines in bronchoalveolar lavage and bronchial biopsies from atopic asthmatic and normal control subjects. Am J Respir Cell Mol Biol 1995;12:477-87.

30 Hamzaoui A, Brahim MB, Zhioua A, et al. Inflammatory response in induced sputum mononuclear cells from patients with acute exacerbation of asthma. Mediat Inflamm 2000;9:147-53.

31 Lukacs NW, Strieter RM, Chensue SW, et al. Interleukin-4-dependent pulmonary eosinophil infiltration in a murine model of asthma. Am J Respir Cell Mol Biol 1994;10:526-32.

32 Gavett SH, Ohearn DJ, Karp CL, et al. Interleukin-4 receptor blockade prevents airway responses induced by antigen challenge in mice. Am J Physiol 1997; 272:L253-61.

33 Cohn L, Tepper JS, Bottomly K. Cutting edge: IL4 independent induction of airway hyperresponsiveness by Th2, but not Th1 cells. J Immunol 1998;161:3813-6

34 Hogan SP, Mould A, Kikutani H, et al. Aeroallergen-induced eosinophilic inflammation, lung damage and airways hyperreactivity in mice can occur independently of IL4 and allergen-specific immunoglobulins. J Clin Invest 1997;99:1329-39.

35 Bentley AM, Hamid Q, Robinson DS, et al. Prednisolone treatment in asthma. Reduction in the numbers of eosinophils, T cells, tryptase-only positive mast cells, and modulation of IL-4, IL-5, and interferon-gamma cytokine gene expression within the bronchial mucosa. Am J Respir Crit Care Med 1996;153:551-6.

36 Sewell WA, Scurr LL, Orphanides H, et al. Induction of interleukin-4 and interleukin-5 expression in mast cells is inhibited by glucocorticoids. Clin Diagn Lab Immunol 1998;5:18-23.

37 Robinson D, Hamid Q, Ying S, et al. Prednisolone treatment in asthma is associated with modulation of bronchoalveolar lavage cell interleukin-4, interleukin-5, and interferon-gamma cytokine gene expression. Am Rev Respir Dis 1993;148:401-6.

38 Coqueret $\mathrm{O}$, Lagent $\mathrm{V}$, Frere $\mathrm{CP}$, et al. Regulation of lgE production by beta-2-adrenoreceptor agonists. Ann NY Acad Sci 1994;725:44-9.
39 Krouwels FH, Hol BE, Bruinier B, et al. Cytokine production by T-cell clones from bronchoalveolar lavage fluid of patients with asthma and healthy subjects. Eur Respir J Suppl 1996;22:95-103s.

40 Ying S, Durham SR, Corrigan CJ, et al. Phenotype of cells expressing mRNA for TH2-type (interleukin 4 and interleukin 5) and TH1-type (interleukin 2 and interferon gamma) cytokines in bronchoalveolar lavage and bronchial biopsies from atopic asthmatic and normal control subjects. Am J Respir Cell Mol Biol 1995;12:477-87.

41 Krug N, Jung T, Napp U, et al. Frequencies of T cells expressing interleukin-4 and interleukin-5 in atopic asthmatic children. Am J Respir Crit Care Med 1998;158:754-9.

42 Matsumoto T, Miike T, Yamaguchi K, et al. Serum levels of soluble IL-2 receptor, IL-4 and IgE-binding factors in childhood allergic diseases. Clin Exp Immunol 1991;85:288-92.

43 Ying S, Humbert M, Barkans J, et al. Expression of IL-4 and IL-5 mRNA and protein product by CD4+ and CD8+T cells, eosinophils, and mas cells in bronchial biopsies obtained from atopic and nonatopic (intrinsic) asthmatics. J Immunol 1997;158:3539-44.

44 Bradding P, Roberts JA, Britten KM et al. Interleukin-4, -5, and -6 and tumor necrosis factor-alpha in normal and asthmatic airways: evidence for the human mast cell as a source of these cytokines. Am J Respir Cell Mol Biol 1994;10:471-80.

45 Tang MLK, Varigos GA, Kemp AS. Reduced interferon-gamma secretion with increased mRNA expression in and atopic dermatitis: evidence for post-transcriptional defect. Clin Exp Immunol 1994;97:483-90.

46 Kroegel C, Julius P, Matthys H, et al. Endobronchial secretion of interleukin-13 following local allergen challenge in atopic asthma: relationship to interleukin-4 and eosinophil counts. Eur Respir 1996:9:899-904.

47 Humbert $M$, Durham SR, Kimmitt $P$, et al. Elevated expression of messenger ribonucleic acid encoding IL-13 in the bronchial mucosa of atopic and nonatopic subjects with asthma. J Allergy Clin Immunol 1997;99:657-65

48 Huang SK, Xiao HQ, Kleine-Tebbe J, et al. IL-13 expression at the sites of allergen challenge in patients with asthma. J Immunol 1995: 155:2688-94.

49 Borish L, Rosenwasser L. TH1/TH2 lymphocytes: doubt some more. J Allergy Clin Immunol 1997;99:161-4.

50 Salvi SS, Babu KS, Holgate ST. Is asthma really due to a polarized T cell response toward a helper T cell type 2 phenotype? Am J Respir Crit Care Med 2001;164:1343-6.

51 Thepen T, Langeveld-Wildschut EG, Bihari IC, et al. Biphasic response against aeroallergen in atopic dermatitis showing a switch from an initia $\mathrm{TH} 2$ response to a $\mathrm{TH} 1$ response in situ: an immunocytochemical study. $J$ Allergy Clin Immunol 1996;97:828-37.

52 Busse WW, Gern JE. Viruses in asthma. J Allergy Clin Immuno 1997:100:147-50.

53 Johnston SL, Pattemore PK, Sanderson G, et al. Community study of role of viral infections in exacerbations of asthma in 9-11 year old children. BM 1995;310:1225-9.

54 Sigurs N. Epidemiologic and clinical evidence of a respiratory syncytial virus-reactive airway disease link. Am J Respir Crit Care Med 2001;163:S2-6.

55 Hussell T, Openshaw PJ. Intracellular IFN-gamma expression in natural killer cells precedes lung CD8 + T cell recruitment during respiratory syncytial virus infection. J Gen Virol 1998;79:2593-601.

56 Tripp RA, Moore D, Anderson L. Th-1- and Th-2-type cytokine expression by activated $T$ lymphocytes from the lung and spleen during the inflammatory response to respiratory syncytial virus. Cytokine 2000:12:801-7.

57 Trinchieri G. Cytokines acting on or secreted by macrophages during intracellular infection (IL-10, IL-12, IFN-gamma). Curr Opin Immunol 1997:9:17-23

58 van der Velden V, Laan MP, Baert MR, et al. Selective development of a strong Th2 cytokine profile in high-risk children who develop atopy: risk factors and regulatory role of IFN-gamma, IL-4 and IL-10. Clin Exp Allergy 2001;31:997-1006.

59 Randolph DA, Stephens R, Carruthers CJ, et al. Cooperation between Th 1 and Th2 cells in a murine model of eosinophilic airway inflammation. J Clin Invest 1999:104:1021-9.

60 Picker MK, Singh Z, Zdraveski JR, et al. Direct demonstration of cytokine synthesis heterogeneity among human memory/effector T cells by flow cytometry. Blood 1995;86:1408-19.

61 Pala P, Hussell T, Openshaw PJ. Flow cytometric measurement of intracellular cytokines. J Immunol Methods 2000;243:107-24.

62 Mehta BA, Maino VC. Simultaneous detection of DNA synthesis and cytokine production in staphylococcal entertoxin B activated CD4+ T lymphocytes by flow cytometry. J Immunol Methods 1997;208:49-59. 